\title{
Analysis on Rainwater Harvesting System as a Source of Non-Potable Water for Flood Mitigation in Metro Manila
}

\author{
Imee V. Necesito · Micah Lourdes A. Felix* · Lee-Hyung Kim \\ Tae Sung Cheong** · Sangman Jeong ${ }^{+}$ \\ Department of Civil and Environ. Eng., Kongju National University, Cheonan City, Republic of Korea \\ * Water Resources and Environmental Department, Korea Institute of Construction Technology, Goyang City, Republic of Korea \\ ** Research Planning Department, National Disaster Management Institute, Seoul City, Republic of Korea
}

\section{마닐라의 홍수저감을 위한 잡용수 대체자원으로서의 가정용우수저류시설 분석}

\author{
Imee V. Necesito · Micah Lourdes A. Felix* · 김이형 · 정태성** · 정상만 \\ 공주대학교 건설환경공학부 \\ * 한국건설기술연구원 수자원 · 환경 연구본부 \\ ** 국립재난안전연구원 연구기획과
}

\begin{abstract}
Excessive precipitation, drought, heat waves, strong typhoons and rising sea levels are just some of the common indicators of climate change. In the Philippines, excessive precipitation never failed to devastate and drown the streets of Metro Manila, a highly urbanized and flood-prone area; such problems are expected to occur frequently. Moreover, the water supply of Metro Manila is dependent only to Angat Reservoir. Rainwater harvesting can serve as an alternative source of raw water and it can mitigate the effects of flooding. The harvested rainwater can be used for: potable consumption if filtered and disinfected; and non-potable consumptions (e.g., irrigation, flushing toilets, carwash, gardening, etc.) if used untreated. The rainfall data were gathered from all 5 rainfall stations located in Metro Manila namely: Science Garden, Port Area, Polo, Nangka and Napindan rain gauge stations. To be able to determine the potential volume of rainwater harvested and the potentiality of rainwater harvesting system as an alternate source of raw water; in this study, three different climatic conditions were considered, the dry, median and wet rainfall years. The frequent occurrence of cyclonic events in the Philippines brought significant amount of rainwater that causes flooding in the highly urbanized region of Metro Manila. Based from the results of this study, the utilization of rainwater harvesting system can serve as an alternative source of non-potable water for the community; and could also reduce the amount of surface runoff that could result to extreme flooding.
\end{abstract}

Keywords : Climate change, Excessive precipitation, Flooding, Metro Manila, Philippines, Rainwater harvesting, Water management

$$
\text { 요 약 }
$$

전 세계 적으로 발생하고 있는 국지성 집중호우, 가뭄, 혹서, 태풍, 해수면 상승 등과 같은 징후는 기후변화가 진행되고 있음을 보여준다. 이러한 기후변화로 인해 일정빈도이상의 과도한 강우가 발생하면 필리핀의 마닐라는 높은 도시화와 홍 수에 취약한 구조 때문에 홍수피해가 빈번하게 발생한다. 마닐라의 홍수조절 기능 및 생활용수 공급은 Angat댐을 통해서 만 관리되기 때문에 홍수방지와 원활한 물공급을 위해 가정용우수저류시설은 최적의 대체자원이 될 수 있다. 가정용우수 저류시설에 의해 공급되는 물은 여과 및 살균과 같은 수처리 과정을 거쳐 식수로 사용될 수 있으며 수처리 과정을 거치 지 않은 잡용수는 세정, 세차, 청소 등의 목적으로 사용할 수 있다. 본 연구에서는 다양한 기후조건을 적용하여 가정용우 수저류시설의 잠재가용량과 잠재가용성을 결정하기 위해 마닐라에 위치한 5 개 강우관측소에서 갈수해, 평수해, 강수해로 구분하여 강우자료를 수집하였다. 필리핀은 대부분의 지역이 도시화되어 과도한 강우 발생시 많은 양의 우수가 발생되었 으며 본 연구의 결과를 통해 가정용우수저류시설의 사용은 잡용수의 대체자원으로서 적절한 대안이 될 것으로 판단된다.

\footnotetext{
+ To whom correspondence should be addressed.

smjeong@kongju.ac.kr
} 


\section{Introduction}

Climate change is hazardous both for the environment, and to all living creatures. Climate change is defined not only by average temperature and precipitation, but also by the type, frequency, and intensity of weather events such as heat waves, cold waves, storms, floods, and droughts (U.S. EPA, 2012). The Intergovernmental Panel on Climate Change (IPCC) forecasted the following to Asian countries: the projection on the freshwater availability will decrease by year 2050; risk in coastal areas will increase due to flooding; and the mortality rate will most likely be decreased due to the diseases associated with drought and flooding (IPCC, 2007).

Philippines is located at the tropics of Southeast Asia with two pronounced seasons, the wet and dry seasons. It has an abundant amount of rainfall with mean annual rainfall of 965 to $4,064 \mathrm{~mm}$. The occurrence of typhoons in area of responsibility of the Philippines has an average of 19.6 typhoons per year (Zoleta-Nantes, 2000). Metro Manila, the National Capital Region (NCR) of the Philippines, constitutes $0.2 \%$ of the whole country. It has a population density of 15,617 persons per sq.km (Ragragio, 2003). Heavy rainfall or strong typhoons usually result to the inundation of rivers and overflowing of dams, which never failed to cause monetary damages or even kill lives. Metro Manila experiences $90 \%$ of the flood events of the country for each year (Daligdig and Besana, 1993); and $31 \%$ of its land area is flood prone which includes Manila, Caloocan, Malabon, Navotas, Pasig, Marikina, Pateros and Taguig (Magno-Ballesteros, 2000). These cities have low elevations with respect to the sea level and it has inferior soil structure composition (Cabanilla, 1996). Almost 98\% of the water demand of Metro Manila comes from Angat Dam while the remaining $2 \%$ comes from groundwater; however, the continuous increase of the population means that additional source of raw water is also necessary (ADB, 2007).

The use of rainwater harvesting system (RWHS) could mitigate the effects of flooding by reducing the volume of stormwater runoff, which occurs if the infiltration rate of the saturated soil is less than the rainfall intensity. A rainwater harvesting system is composed of a catchment area, a delivery system and storage (Worm and Hatum, 2006). The catchment area used in this system is usually made of impervious materials (e.g. metal roofs); the delivery system is responsible for transporting the harvested rainwater to the storage (e.g., gutters, pipes); and lastly, the rainwater storage should have the capacity to store the rainwater to make sure that the availability of rainwater can be used whenever it is necessary.

Rainwater harvesting is a promising alternative solution for water shortages in Edo State (Oni et al., 2008). In Dhanbad, India, rooftop rainwater harvesting with recharge pits were done for groundwater recharge (Patra and Gautam, 2011). Rainwater harvesting has numerous advantages: it is free, zero hardness, sodium-free, used for landscape and irrigation, reduces stormwater runoff, and reduces consumer's utility bills (Krishna, 2003).

In 1982, Japanese Sumo Association stocked rainwater to mitigate urban flooding and the stocked rainwater can be used for water conservation as an emergency water supply (UNEP, 2012). Rainwater harvesting can also prevent pollution, inundation, and excessive storm water runoff (Findlay, 2009). The National Hydraulic Research Institute of Malaysia researched that a household consisting of two adults and four school-going children, can consume $34 \%$ of the collected rainwater for non-potable purposes for a month in Malaysia (Che-Ani et al., 2009). In the United States, the utilization of rainwater harvesting systems on a domestic scale was implemented to reduce the groundwater and municipal water consumptions, which was also considered as a Best Management Practice to reduce stormwater runoffs (Kowalsky and Thomason, 2010). The utilization of rainwater harvesting using Low Impact Development (LID) techniques to stormwater management was also proved to be effective (Majid and Rusli, 2012).The implementation of the BMPs, including rainwater harvesting with LID strategies, was tracked with the Runoff Reduction Model (RRM) to comply with the stormwater quality and quantity requirements (Battiatia, 2010).

An analysis on the reliability of rainwater tanks were investigated under different climatic conditions that had significant differences in rainfall amounts, driest, average, and wettest years (Imteaz et al., 2011a). Three different rainfall years (i.e., dry, average and wet years corresponds to the 1st, 5th and 9th deciles, respectively) were used to optimize the design of rainwater tanks (Imteaz et al., 2011b). Also, the potentiality of the utilization of rainwater harvesting system for varying non-potable water consumption of domestic dwellings were analyzed for different rainfall years (Felix et al., 2011).

This study analyzed the potentiality of rainwater 
harvesting to mitigate the flooding effects of climate change; and the potentiality of the use of RWHS as a substitute source of raw water for Metro Manila.

\section{Materials and Methods}

\subsection{Study Area}

Metro Manila has a total land area of $636 \mathrm{sq} . \mathrm{km}$. and it consists of 16 cities and 1 municipality (NNC, 2012). The rainfall data were gathered from all 5 rainfall stations located in Metro Manila namely: Science Garden, Port Area, Polo, Nangka and Napindan rain gauge stations; the location of each station is shown in Fig 1.

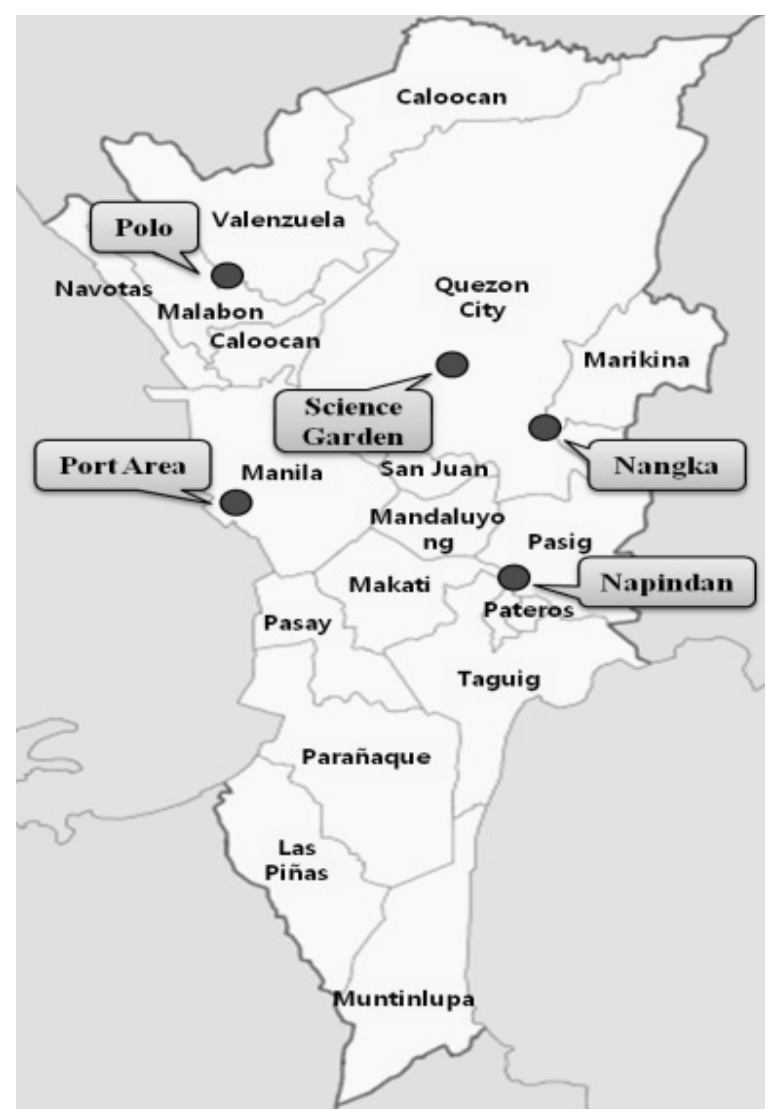

Fig. 1. The scope of the study area and the location of all rain gauge stations in Metro Manila.

\subsection{Rainfall Analysis}

A total of 11 rainfall years data were used for Science Garden and Port Area stations (i.e., year 2000 to 2010), 11 rainfall years data for Polo station (1998 to 2008) and 5 rainfall years data for both Nangka and Napindan stations (i.e., years 2003 to 2006). The rainfall data of
Science Garden, Port Area and Polo stations were gathered from the Philippine Atmospheric, Geophysical and Astronomical Services Administration (PAGASA, 2011). Data from Nangka and Napindan stations were also considered despite its limited availability, primarily because both rain gauge stations were new; both the rain gauge stations are managed by the Metro Manila Development Authority (EFCOS/MMDA, 2011).

To determine the different climatic conditions, three rainfall years were considered. The annual rainfall depth was used to determine the dry, median and wet years for each station. However, due to the variability of the distribution of rainfall in the study area, this study limits the analysis only to the three rainfall years of one station. The analysis limits the study to three rainfall years which could represent the different climatic conditions. The station which had the highest rainfall variability was considered. After determining the three rainfall years, all rainfall data were still utilized for the purpose of determining the average annual rainfall that could represent the whole study area. The percentage of the average rainy days was calculated by dividing the annual total number of days with precipitation with the total number of days of the given year.

The classification of monthly rainfall depths could be subdivided into three monthly rainfall depth ranges: months with rainfall depths of less than $100 \mathrm{~mm}$, greater than $200 \mathrm{~mm}$, and greater than $500 \mathrm{~mm}$ are categorized under the dry month, wet month and the heavy precipitated month, respectively (Morris and Rumbaoa, 1985).

Four types of tropical cyclones occur in the Philippines and it can be classified according to its intensity. Tropical Depression (TD), Tropical Storm (TS), Typhoon (T), and Super Typhoon (ST) are the classification of tropical cyclones, in ascending magnitudes, for countries located at North Western Pacific areas; it is adopted from Joint Typhoon Warning Center (MSS, 2012).

\subsection{Rainwater Harvested}

Estimation of the potential rainwater that can be harvested was calculated to determine the amount of rainwater that a specific catchment area could harvest. The volume of rainwater harvested can be utilized for non-potable consumptions since this study included neither treatment nor measures of water quality. Estimation on the volume of the annual rainwater harvested was calculated 
by determining the product of the annual rainfall depth and the catchment area of the rainwater harvesting system; disregarding losses. The annual rainfall depth used were from the dry, median and wet annual rainfall years; wherein the catchment areas considered were 50 sq. m, 150 sq. $\mathrm{m}$ and 300 sq. m., which could easily represent the typical catchment areas of the average houses in Metro Manila. Furthermore, the distribution of the annual rainwater harvested was calculated by considering that the whole catchment area of Metro Manila utilizes the total annual rainfall for the rainfall years.

\section{Results and Discussions}

3.1 Selection of dry, median and wet rainfall years
The average annual rainfall depths and the percentage of rainy days of five rain gauge stations in Metro Manila are shown in Fig 2. Polo station was observed to have the highest rainfall variation; therefore, the three rainfall years of Polo station were exclusively used to represent the three climatic conditions for the study area (i.e., years 2005, 2003 and year 2000 correspond to the dry, median and wet years, respectively). The average rainy days percentage of the Port Area, Science Garden, Polo, Napindan and Nangka stations were 39\%, 46\%, 39\%, $31 \%$ and $38 \%$, respectively; wherein the average occurrence of rainfall events in all rain gauge stations is $38.5 \%$. It indicates that in terms of rainfall days, the selection of the rainfall years of Polo station is admissible.

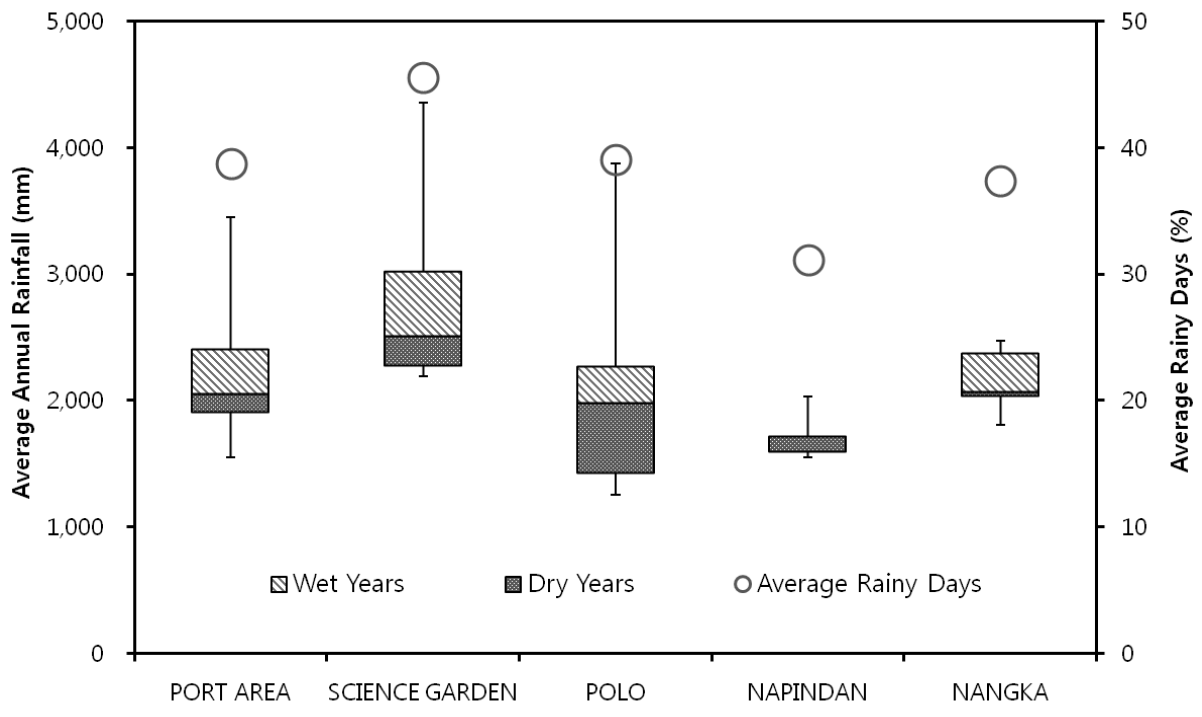

Fig. 2. Annual rainfall depths in $\mathrm{mm}$ and the average rainy days in percent in all five rain gauge stations.

\subsection{Rainfall analysis}

After determining the three rainfall years that were used in this study; the annual rainfall depth of years 2000, 2003 and 2005 were used to calculate the average rainfall depth for each year from all five rain gauge stations. It is shown in Fig 3 that the months June to October of the dry year exceeded the monthly rainfall of $200 \mathrm{~mm}$, which suggests that it falls under the wet month category. Hence, from November to May, whose monthly rainfall depths were less than $100 \mathrm{~mm}$ were classified as dry months. For the median year, the months May to
September are wet months, while the months October to April falls under the dry month category. The wet year had seven wet months which started from the month of May until November. However, three of the seven wet months were also classified as heavy precipitated months, wherein its monthly rainfall exceeded the $500 \mathrm{~mm}$ boundary. Also for the wet year, the months January to April falls under the dry month category; thus, the month of December is categorized under the average precipitated month. The wet year was 2.1 and 1.9 times greater than the dry and median years, respectively. It clearly proved the different precipitation conditions between the three rainfall years in Metro Manila. 


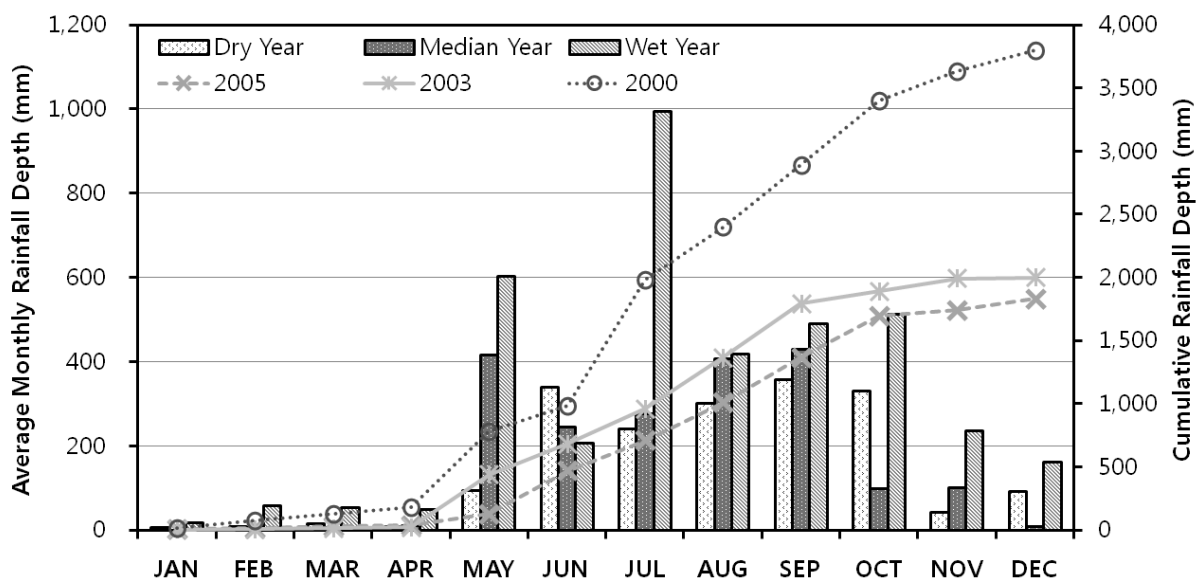

Fig. 3. Average monthly rainfall depth and cumulative rainfall depth of the dry, median and wet rainfall years of all five rain gauge stations.

The average monthly rainfall depth ranges are shown in Fig 4, wherein the monthly rainfall depth range for both dry and median years were observed to have 7 dry months, 5 wet months and no month with heavy precipitation. While the wet year was observed to have 4 dry months, 4 wet months, 3 heavy precipitated months and an average month with a monthly rainfall depth greater than $100 \mathrm{~mm}$ but less than $200 \mathrm{~mm}$. The wet year had the maximum amount of rainfall depth, despite having a lesser number of wet months, due to the occurrence of 3 heavy precipitated months (i.e., May, July and October). These 3 heavy precipitated months were primarily due to the occurrence of 2 tropical depressions, 2 tropical storms and 2 typhoons.

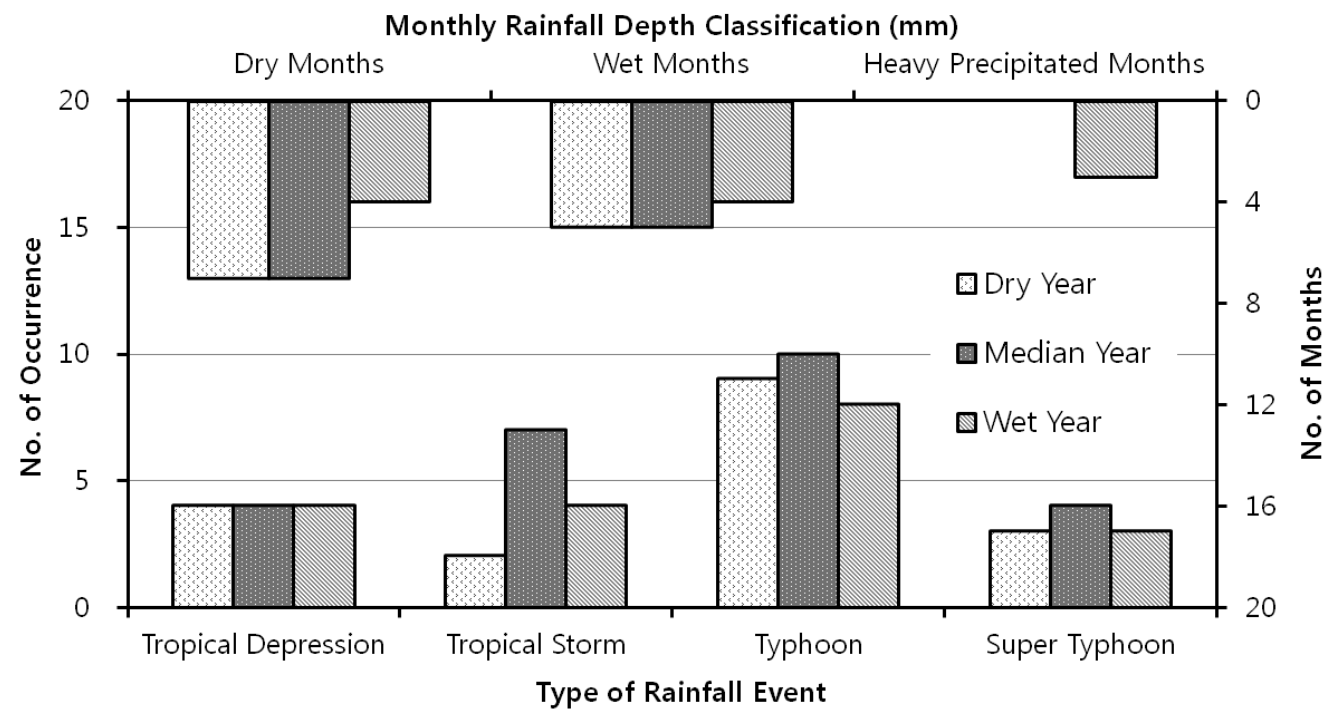

Fig. 4. Types of rainfall events and monthly rainfall depth range of the three rainfall years in Metro Manila.

The different types of tropical cyclones are also shown in Fig 4 as well as monthly rainfall classifications of dry, median and wet rainfall years. All cyclonic events were observed all throughout the Philippines; therefore, not all tropical cyclones brought significant amount of rainfall in Metro Manila. During the dry year, a total of 18 typhoon events were recorded in the Philippines. However, only $33 \%$ of these cyclonic events brought significant amount of rainfall over the region of Metro Manila. The median year had $44 \%$ significant events out of the total of 25 events. Furthermore, the wet year had a total of 19 cyclonic events with only $68 \%$ of the total events brought significant amount of rainfall. It is evident that the occurrences of typhoon events are most probable to occur; it governs all the 4 classification of tropical cyclones. 


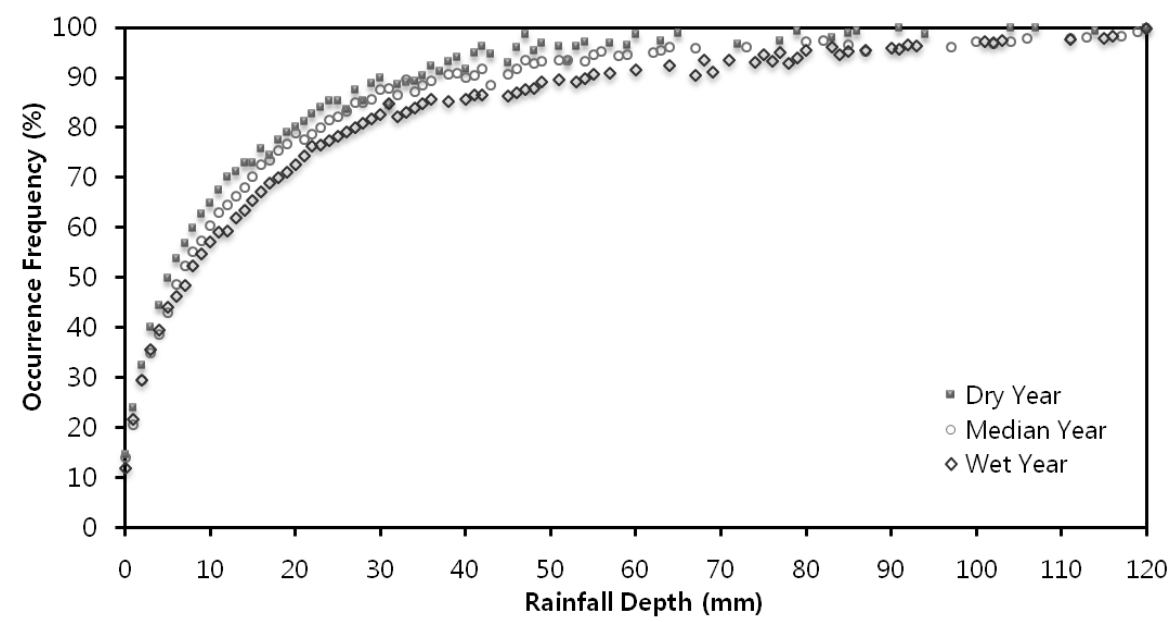

Fig. 5. Average annual occurrence frequency percentage from five rain gauge stations for the dry, median and wet rainfall years.

Fig 5 shows the average occurrence frequency of rainfall depth from all five rain gauge stations for dry, median and wet rainfall years; wherein, $35 \%$ of the total rainfall events have approximately less than $3 \mathrm{~mm}$ of rainfall depths. It is also illustrated in the figure that the curve of all three rainfall years almost coincided with each other from $0 \mathrm{~mm}$ to $3 \mathrm{~mm}$; which suggest that, a rainfall event with less than $3 \mathrm{~mm}$ rainfall depth has a $35 \%$ probability of occurring. After the $3 \mathrm{~mm}$ rainfall depth, the graphs for each for all different rainfall years diverged from each other until it coincided again at the $95 \mathrm{~mm}$ rainfall depth with less than $95 \%$ probability of occurring. At the point where the three rainfall years reached $80 \%$ of occurrence frequency, uniform spacing between curves were observed. The rainfall depths at this point were less than $20 \mathrm{~mm}, 23 \mathrm{~mm}$ and $26 \mathrm{~mm}$ for the dry, median and wet rainfall years, respectively. The occurrence frequency curve shows that as the annual rainfall intensifies, its expected rainfall depth per rainfall event is also expected to increase.

\subsection{Rainwater Harvesting}

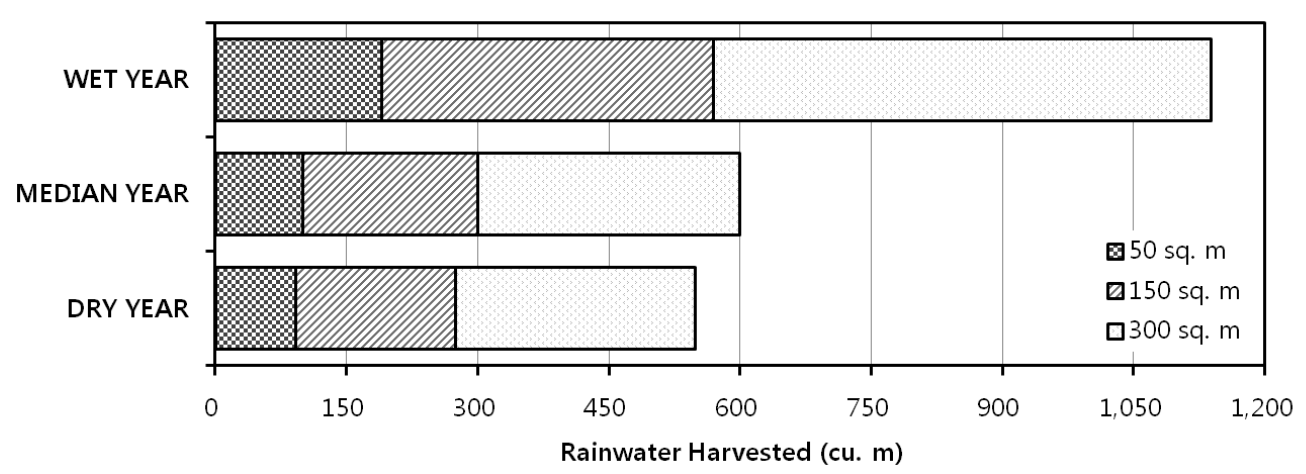

Fig. 6. Volume of rainwater harvested for the dry, median and wet rainfall years with different catchment areas (i.e., 50 sq. $\mathrm{m}, 150$ sq. $\mathrm{m}$, and 300 sq. m).

Fig 6 shows the potential rainwater volume harvested for the dry, median and wet rainfall years for different catchments areas (i.e., 50 sq. m., 150 sq. m., and 300 sq. $\mathrm{m}$.). The volume harvested for both median and dry years had a difference of $50 \mathrm{cu}$. m. It suggests that despite the circumstances of a dry year, having a 300 sq. m. of catchment area could still harvest almost $550 \mathrm{cu} . \mathrm{m}$. of rainwater for a whole year; while, a total of 1,150 cu. $\mathrm{m}$. of rainwater can be harvested for the wet year which is almost half the volume capacity of an Olympic pool (i.e., a standard Olympic pool has a capacity of 2,500 cu. m.). 


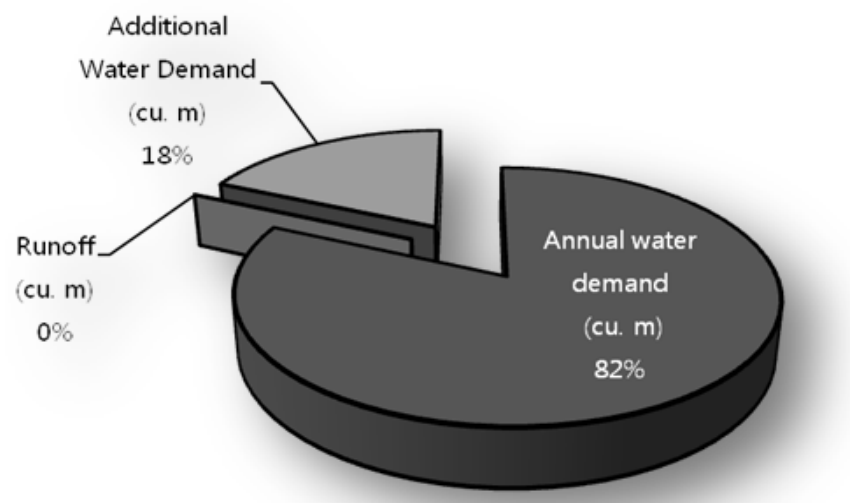

Dry Year (a)

(b)

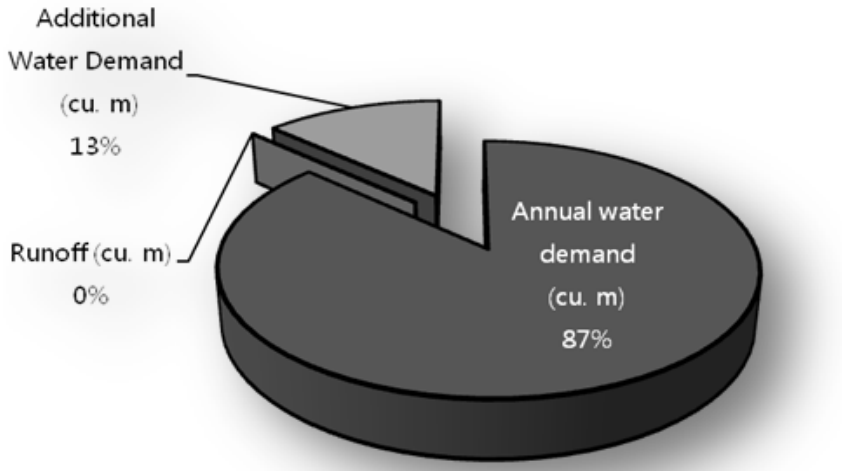

Median Year

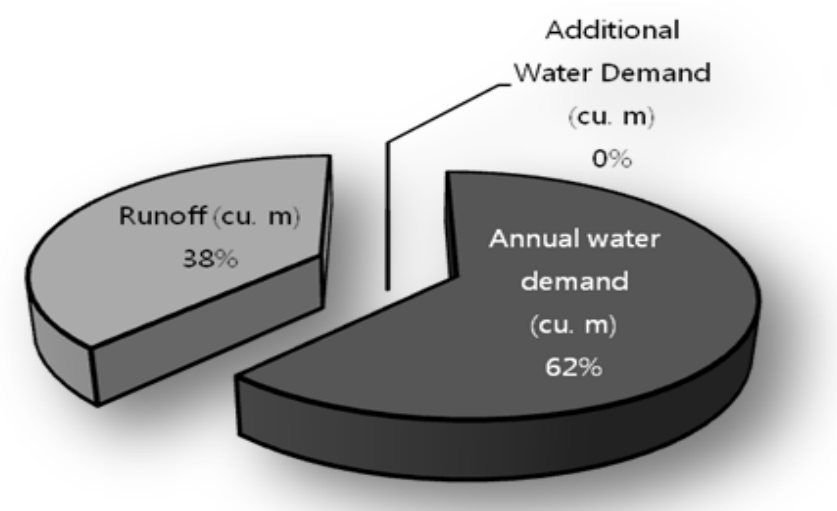

Wet Year (c)

Fig. 7. Water allocation for the a) dry year, b) median year, and c) wet year.

The annual water allocation for the dry, median and wet rainfall years for Metro Manila are shown in Fig 7(a), Fig 7(b) and Fig 7(c). Metro Manila consumes almost 1,500 million cu. m. of surface water annually, drawn out from Angat Dam. The surface water annually drawn out from Angat Dam was also used as the Annual water demand in this study. The runoff or additional water demand was determined by subtracting the estimated annual rainwater harvested with the annual water demand. If volume of water resulted to a negative value, it is considered as an additional water demand needed to sustain the original water demand; otherwise, considered 
as runoff. It is shown in Fig 7(c) that the wet year yielded $38 \%$ of surface runoff, of the total annual rainwater. While, the annual water demand consisted only of $62 \%$ of the total rainwater volume, which suggests that the wet year is capable of providing the total annual water demand being drawn out from Angat Dam. Fig 7(a) and Fig 7(b) shows that both the median and dry years have rainwater volumes with less than the annual water demand, which suggests that both rainfall years can only provide as much as $80 \%$ of the total water demand for each rainfall year. Furthermore, both the median year and the dry year should retrieve almost $20 \%$ of the total annual demand from Angat Dam to suffice the deficient annual volume of raw water.

\section{Conclusion}

The frequent occurrence of cyclonic events in the Philippines brought significant amount of rainwater that causes flooding in the highly urbanized region of Metro Manila. Despite a lesser amount of rainfall during dry and median years, it can still produce a significant amount of non-potable water if harvested. However, during wet rainfall years, the amount of rainfall was observed to be excessive.

The use of RWHS could minimize the water demand being drawn out from Angat Dam and the surface runoff which causes flooding. The main problem on finding an alternative source of water supply can be resolved by the use of RWHS. The rainwater is free, Metro Manila has abundant rainfall, and the rainwater is soft water with no hard metals which could require only basic water treatments. Rural areas with no water supply coverage can use the RWHS to have a safe and free access for their water consumption. Since $2 \%$ of the water consumption of Metro Manila is from groundwater, and some parts of Metro Manila is located along side of a lake and a sea, salt water intrusion may also pose a big problem. Therefore, to be able to minimize these effects of this problem, rainfall runoff can be injected into the ground or retention basins maybe used for groundwater recharge. To be able to utilize the rainwater harvested for non-potable consumptions: the water should be subjected to basic water treatments to remove inorganic pollutants by using filtration media, activated carbon or sand filtration. While for potable water consumptions, such as drinking or laundry purposes, disinfection of the harvested water is necessary; it can be done by subjecting the water to ultraviolet treatment or by chlorine treatment. Rainwater storages may vary from a small tank to a large cistern tank depending on the primary purpose of the consumer. The storage sizing of rainwater harvesting storage was not included in this study, because it requires detailed data, which were not available.

To further utilize the rainwater, the government of the Philippines should encourage its citizens to use rainwater harvesting systems not only on flood-prone, highly urbanized areas but also to rural areas where neither the groundwater nor the municipal waters were made available for their water source. Since this study only focused on the estimation of rainwater harvested for Metro Manila, future studies on storage sizing should be done to achieve efficient and practical rainwater storages depending on household conditions.

\section{References}

Asian Development Bank (ADB) (2007). Country Paper: Philippines. Asian Water Development Outlook 2007.

Battiata, J., Collins, K., Hirschman, D., and Hoffmann, G. (2010). The Runoff Reduction Method. Universities Council on Water Resources. Journal of Contemporary Water Research and Education. (146). pp. 11-21.

Cabanilla, A.Q. (1996). Sustainable Development in Urban Management: The Metro Manila Experience. Presented at: Urban Environmental Management for Sustainable Development. Pasig: Development Academy of the Philippines. March 7, 1996.

Che-Ani, A. I.; Shaari, N.; Sairi, A.; Zain, M. F. M.; and Tahir, M. M. (2009). Rainwater Harvesting as an Alternative Water Supply in the Future. European Journal of Scientific Research. (34:1) pp. 132-140.

Daligdig, J., \& Besana, G. (1993). Seismological hazards in Metro Manila, In Disaster Prevention and Mitigation in Metropolitan Manila (pp. 9-42). Quezon City, Philippines: Department of Science and Technology and Philippine Institute of Volcanology and Seismology.

Effective Flood Control Operating System of Metro Manila Development Authority (EFCOS/MMDA) (2011). Pasig City. Data Acquired: 2011

Felix, M.L.A.; Maniquiz, M.C.; Seo, S; Kim, L.H.; Jeong, S. (2011). Analysis on the Potentiality of Domestic Rainwater Harvesting in Metro Manila. Korean Wetlands Society. 13(3). pp. $633-641$. 
Findlay, D. (2009). Rainwater Collection,Water Law, and Climate Change: A Flood of Problems Waiting to Happen. North Carolina Journal of Law \& Technology. 10 N.C. Jolt Online Ed. p.80

Imteaz, M. A.; Ahsan, A.; Naser, J.; and Rahman, A. (2011a). Reliability analysis of rainwater tanks in Melbourne using daily water balance model. Resources, Conservation and Recycling, 56, pp. 80-86. Imteaz, M. A.; Shanableh, A; Rahman, A. and Ahsan, A. (2011b). Optimisation of rainwater tank design from large roofs: A case study in Melbourne, Australia. Resources, Conservation and Recycling. 55, pp. 10221029.

Intergovernmental Panel on Climate Change (IPCC). (2007). Summary for Policymakers, in Climate Change 2007: Impacts, Adaptation and Vulnerability. Contribution of Working Group II to the Fourth Assessment Report of the Intergovernmental Panel on Climate Change. Cambridge University Press. p. 17. Available at: http://www.ipcc.ch/pdf/assessment-report/ar4/ wg2/ar4-wg2-spm.pdf Retrieved at: February 2012.

Kowalsky, G. and Thomason, K. (2010). Rainwater Harvesting and Re-Use: A Tool for Stormwater Runoff Reduction. Professional Development Series. Available at: http://www.conteches.com/

Krishna, H. (2003). An overview of rainwater harvesting systems and guidelines in the United States. Proceedings of the First American Rainwater Harvesting Conference; 2003 Aug 21-23; Austin (TX).

Magno-Ballesteros, M. (2000). Land Use Planning in Metro Manila and the Urban Fringe: Implications on the Land and Real Estate Market. Philippine Institute for Development Studies.

Majid, M. R. and Rusli, N. Site-scale Rainwater Harvesting: Potential Applications of Low-ImpactDevelopment Techniques in Malaysia. Available at: http://www.academia.edu/attachments/3859691/download _ file. Accessed at: February 2012

Meteorological Service Singapore. (MSS). Tropical Cyclone Classification. Available at: http://www.weather.gov.sg/ wip/pp/ssops/typhoon/tsclassification. Retrieved: February
2012.

Morris, R. A. and Rumbaoa, Jr. F. M. (1985). Classification of Philippine Rainfall Patterns. IRRI Research Paper Series. (109).

National Nutrition Council, NNC (2012). NCR Profile. Available at: http://www.nnc.gov.ph/index.php?option= com_k2\&view=itemlist\&task=category\&id=89:ncr-profile

Oni, S. I., Ege, E., Asenime, C., and Oke, S. A. (2008). Rainwater Harvesting Potential for Domestic Water Supply in Edo State. Indus Journal of Management \& Social Sciences. 2(2), pp. 87-98.

Patra, A. D. and Gautam, S. (2011). A pilot scheme for rooftop rainwater harvesting at Centre of Mining Environment, Dhanbad. International Journal of Environmental Sciences. 1(7). pp. 1542-1548.

Philippine Atmospheric Geophysical, Services Administration (PAGASA). (2011). Science Garden Compound, Agham Road, Diliman, Quezon City, Philippines.

Ragragio, J. M. Urban Slums Reports: The case of Manila, Philippines (2003). Available at: http://www.ucl.ac.uk/ dpu-projects/Global_Report/pdfs/Manila. pdf

U. S. Environmental Protection Agency (U.S. EPA). (2012). Climate Change Indicators in the United States. Available at: http://epa.gov/climatechange/ indicators/pdfs/ ClimateIndicators_full.pdf Retrieved at: January 2012.

United Nations Environment Programme (UNEP). Rainwater Harvesting and Disaster Management. Rainwater and the MDGs Booklet. Available at: http:// www.unep.org/ pdf/RWH/disaster_management.pdf Retrieved: February 2012

Worm, J. and Hattum, T. V. (2006). Rainwater Harvesting for Domestic Use. pp. 12-13

Zoleta-Nantes, D.B. (2000). Flood Hazards in Metro Manila: Recognizing Commonalities, Differences, and Courses of Action. Social Science Diliman. p. 63

논문접수일 : 2013년 04월 08일 심사의뢰일 : 2013년 04월 09일 심사완료일 : 2013년 04월 17일 